\title{
O segredo é o relacionamento
}

\author{
Relationship is the secret
}

\section{El secretoto es la relación}

\author{
Juan José Dutto ${ }^{1}$
}

A Asociación de Defensores del Pueblo de la República Argentina congrega todos os defensores municipais e provinciais do País. Temos defensores no nível estadual, provincial e municipal, embora nem todas as cidades tenham tido ainda a iniciativa de criar esse instituto, que fica restrito às maiores cidades argentinas.

O trabalho das defensorias aumenta muito nos períodos de crise pelos quais temos passado e é justamente aí que temos obtido um amplo reconhecimento por parte dos cidadãos.

Um dos maiores problemas dos períodos de crise econômica é o desemprego. E, sintomaticamente, essa é a origem das maiores demandas que recebemos. Os jovens, principalmente, precisam entrar no mercado de trabalho, mas a falta de políticas públicas e planos de estudo que garantam essa inserção gera um grave problema social e econômico. Recebemos também na Argentina muitas demandas relacionadas às questões ambientais e de urbanismo.

A ampla aceitação que temos hoje no País deve-se, com certeza, ao modo como nos relacionamos com a população. Vivemos praticamente junto com ela, em uma interação bastante intensa, e experimentamos a gravidade dos problemas que ela nos traz. Isso faz com que se crie um elo de confiança entre os defensores e o povo.

1 Psicólogo social, é defensor del pueblo da Província do Neuquén (Argentina) e presidente da Asociación de Defensores del Pueblo de la República Argentina. 
Por essas e outras, a experiência nesse cargo traz muito enriquecimento pessoal e também muita tensão. Há pouco enfrentamos uma situação que pode bem ilustrar o nosso trabalho cotidiano. Jovens da província de Neuquén que moravam de modo irregular foram expulsos de suas casas por força policial. Nós interferimos na situação, mediando o conflito de interesses entre a província e o município, porque esse era realmente o fundamento do problema que resultou na expulsão dos jovens. Evitamos a violência policial e conseguimos estabelecer um acordo que satisfez a ambos os lados em conflito, ao município e à província.

Desse modo, temos um alto índice positivo de resolução de conflitos, de cerca de $80 \%$, que nos capacita a merecer a confiança da população. A imprensa, por exemplo, tem sido uma grande aliada não só para difundir esse nosso tipo de trabalho, mas também para colaborar conosco nas decisões, esclarecendo a população acerca das negociações que empreendemos. 